\title{
The Potency of Design in Holocaust Exhibitions. A Case Study of The Imperial War Museum's Holocaust Exhibition (2000)
}

\author{
Diana I. Popescu
}

\begin{abstract}
Holocaust exhibitions are known for their unique iconography, often constructed by means of exhibition design. This article focuses on how visitors construct meaning based on display choices made by exhibitions designers. It presents insights from an audience research study which was conducted with young visitors of the Holocaust Exhibition at the Imperial War Museum in London. It addresses how design choices impact on public engagement and understanding of the Holocaust Exhibition. By drawing on visitor comments, this article shows that design plays a significant role in shaping visitors' understanding of the Holocaust, as well as their level of engagement, focus and emotional response. It further makes several practical suggestions, informed by visitor feedback, regarding the development of new Holocaust exhibition designs.
\end{abstract}

Key words: Holocaust exhibition design, visitors at Holocaust exhibitions, Imperial War Museum, young people, emotion and cognition, commemoration and education

\section{Holocaust Exhibition Design - Meaning and Practice}

As the Holocaust fades further into history, Holocaust museums are actively seeking new ways of representing this past in their exhibitions. In this pursuit, the role of the exhibition designer is crucial in ensuring that exhibition content is made accessible and engaging to audiences. Exhibition design is an 'enormously engrossing and demanding task of developing the very means of content delivery' (Klein 1991: 45). It requires sensitivity to the 'vital connection' between an exhibit's physical design and its content (Rabinowitz 1991: 37; Roppola 2012: 8). Design facilitates the transmission of content and influences the visitor's ability to create meaning. 'Meaning' implies not just the acquisition of knowledge, but also an awareness of the relevance of that knowledge, on a personal and collective level. The meaning that a member of the public takes from an exhibition arises from a 'transactional process' which occurs between exhibition developer and the visitor. The developer chooses how to shape the aesthetics and content of displays. Visitors 'respond to these choices and construct singular experiences' (Roppola 2012: 262). Design elements such as colour, lighting, font styles of textual displays, the use of audio-visual materials, interactivity, the organization of displays in space, all create 'complex orchestrations' which aim to resonate with visitors. 'It is through these complex orchestrations that the potential exists for catalysing visitors' contemplative and critical engagement with the content of displays' (Roppola 2012: 262).

In Holocaust exhibitions, certain elements of design such as: use of the colour black, dark environments and narrow passageways are particularly common. These elements often have symbolic meaning. For instance, 'restrictive, dark spaces and disrupted pathways [...] disorientate or make the visitor feel uneasy, evoking some of the horror and dislocation of the Holocaust', argues Rebecca Jinks (Jinks 2013: 146). They impact on visitors' mood: 'changes in lighting and floor coverings shift mood and sensory perceptions' (Greenberg 2007: 113). These elements are a part of a 'number of tropes from the Holocaust museum installation genre' (Greenberg 2007: 113). They reflect exhibition design trends targeting the emotions of the visitors (Messham-Muir 2004). However, the effectiveness that these design decisions have in engaging the emotions of visitors have not yet been widely assessed using empirical 
methods. There is therefore a need to understand how design choices catalyse the 'inward journey' of the visitor experience (Yellis 2010: 92; Roppola 2012).

Exhibition critics tend to speak on behalf of the visitor, without directly collecting visitor responses (Macken-Horarik 2004: 12). Although visitors to museums and sites of difficult heritage are nowadays recognized, according to Eilean Hooper Greenhill, as 'active interpreters and performers of meaning-making practices within complex cultural sites', interdisciplinary scholarly attempts to understand visitor motivations, expectations, and experiences are still slow to develop (Hooper Greenhill 2006: 362). This article will address the question of audience experience in this case at a museum of difficult knowledge.

Not just critics, but also exhibition designers tend to overlook the importance of obtaining visitor feedback, often relying on 'under-articulated conceptualisations of visitor experience' (McCarthy and Ciolfi 2008: 248). In the case of Holocaust museums, Hannah Holtschneider also notes that 'literature evaluating Holocaust exhibitions [...] assumes familiarity by the audience with the history of the Holocaust' which for many visitors may not be the case (Holtschneider 2007: 85). She goes on to explain how the critics wrongly assume that their own responses to exhibitions also represent those of visitors: 'the critic's own observations about his or her behaviour in response to the exhibition and anecdotal observations of other visitors to Holocaust exhibitions assume the status of normative responses to the displays' (Holtschneider 2007: 85). Since the time of her writing, evidencebased studies into visitor responses to exhibitions have been carried out by researchers and museum professionals. Examples include the unpublished research conducted by Optimisa Research (2016) (commissioned by the Imperial War Museum) into knowledge gained from the Holocaust Exhibition by audiences between 16 and 34 years of age (Donnelly 2018). This and other studies contribute to a growing visitor literature measuring the level of knowledge and understanding of the Holocaust among younger generations. Thus far, scholarly research into Holocaust exhibition design was concerned with the metaphoric meanings of memorial museum architecture (Shosh Rotem 2013; Neuman 2014) characterized by specific elements of design such as the presence of concrete surfaces and columns, architectural voids, inclined surfaces and darkened spaces. Some of these architectural elements have become iconic, such as Daniel Libeskind's Holocaust Tower, or his concrete field of columns, placed on an uneven surface, in the Jewish Museum in Berlin. Other iconic elements include narrow and dark spaces, which introduce the visitor to particularly difficult aspects of the subject matter, such as deportations of the prisoners to death or concentration camps, the conditions in the camps, and the extermination process. Holocaust exhibitions are known to display personal items such as shoes and clothing which belonged to the victims and which arguably help the visitor to grasp 'the magnitude of the Holocaust horror' (Casey 2005: 84). Other display strategies invite identification with victims such as the passport-sized identity cards containing personal details and the photograph of a Holocaust victim, which are offered to visitors as they enter the Holocaust Exhibition at the US Holocaust Memorial Museum (USHMM) in Washington DC (Patraka 1999: 144).

Design choices certainly have an impact on the visitor. In his analysis of comments left by visitors after their viewing of the Holocaust Exhibition at the USHMM, Michael BernardDonals notes that: 'a number of visitors were quite conscious of the space and the design of the museum, and the extent to which it affected their understanding of the events depicted within it' (Bernard-Donals 2018: para. 22). He further remarks how the physical space of the museum exhibition turns into a symbolic realm wherein visitors draw connections between the Holocaust and other events. The exhibition space is thus transformed into a performative space of reflection.

In contrast to the assumptions regarding visitor responses to Holocaust exhibitions, this article seeks to bring the voices of visitors into the foreground. I aim to address how visitors' historical understanding of the Holocaust is informed by the choices made by exhibition designers. How do visitors actually react to iconic design elements such as: dark/well-lit spaces, spatial layout, proximity to artefacts and interactive displays? Are disorientation and unease essential aspects of visitor experience? Are visitors responding to the exhibition design in the way designers expect, or do they respond in radically different ways? By examining 
these questions, this article aims to contribute to the ongoing conversation about how the impact of museum exhibitions can be measured in a meaningful way by means of empirical research. In this attempt to assert the value of the voice of the ordinary visitor, I will - as far as the research sources allow me - compare designer expectations with the audience response gathered during this research study.

The audience research study was conducted between March and June 2017 and kindly supported by the Imperial War Museum's Learning Programme Manager, Rachel Donnelly. This research study focuses on responses from British youth aged between 16 and 18 years, who are among the key target audiences of this exhibition, and of other Holocaust exhibitions worldwide. The students participating in this study came to the Imperial War Museum with their teachers on organized visits and took an audio guided tour which has influenced their engagement with this exhibition.

From its outset, this work is informed by an understanding of the participating young visitors as 'skilful performers' (rather than as passive and uncritical recipients) who take an active and reflexive role as interpreters of exhibitions (Bagnall 2003; Roppola 2012: 41). Also, their experience is understood to be a 'transactional process' shaped at the intersection of their personal interests, expectations and prior knowledge, the influence of other people, wider sociocultural factors, and the immediate physical environment in which visitors find themselves (Falk and Dierking 1992, 2000). While these are important factors which influence visitor experience, this study focuses specifically on elements of design which create the aesthetic of the exhibition: lighting, spatial layout, artefact arrangements, and interactive elements. However, admitting that form and content are closely intertwined and given that the studied audience took an audio guided tour, I will interpret how content transmitted through the audioguide might contribute to their experience. I should clarify that text panels are not regarded as primary elements of design. However, their placement within the exhibition space, the font size and length influence public perceptions and interact with other design elements. Text panels will therefore be discussed where it is essential to understand the impact of design elements mentioned above.

Although the Holocaust Exhibition is about to be replaced with new Holocaust and Second World War Galleries to open in 2021, this analysis remains relevant for several reasons: it is the first study to offer insight into visitor reactions to specific elements of the Imperial War Museum's exhibition design and content. Since many design tropes adopted by this exhibition are common to other Holocaust exhibitions (especially in the Anglophone countries), this analysis hopes to advance understanding of visitor experience at Holocaust museums - a field of study still in infancy. I hope to provide curators of future exhibitions with food for thought with regards to how visitors construct meaning under the influence of design choices. And finally, based on this study, I suggest a few novel ideas as to how future exhibitions dedicated to the Holocaust could be designed to foster a deeper level of engagement with and understanding of the Holocaust among new generations of visitors for whom this history is a distant past.

This study further feeds into literature on the impact of museum exhibitions on visitors, and it aims to contribute towards understanding how young visitors engage with 'dark' subject matters.

\section{The Holocaust Exhibition at the Imperial War Museum, London}

The Imperial War Museum (London) is uniquely placed within Britain's museum landscape to offer a complex historical narrative of twentieth century World Wars and modern-day conflict. This goal is reflected in its institutional definition as the 'leading authority on conflict and its impact, focusing on Britain, its former Empire and the Commonwealth, from the First World War to the present'. 'Since its opening in June 2000 in London, the Holocaust Exhibition has been a prolific subject of scholarly writing (critics have discussed issues relating to the exhibition's representation of historical narrative, of the victims and of the perpetrators, representations of Britain's involvement in the war, in particular the liberation of Bergen-Belsen, and issues that position the museum in relation to Britain's colonial past (see Kushner 2002; Lawson 2003; Wollaston 2005; Cole 2006; Holtschneider 2007, 2011; Jinks 2013; Pearce 2014; Stiles 
2016)). While it is not within the scope of this present study to reiterate critical coverage of the exhibition, specific remarks relating to the exhibition's conceptual framing, layout and design shall be briefly discussed.

The Holocaust Exhibition is Britain's first and only large-scale exhibition dedicated to this subject. It remains, as Suzanne Bardgett, the founding Project Director, described it, 'a watershed in the history of the Museum and in the public understanding of this event in the UK' (Bardgett and Imperial War Museum 2010: 2), drawing public acclaim and a record number of over four million visitors since its opening. The Holocaust Exhibition has its own 'special identity' and 'special ambience' (Bardgett 2004: 155). This is in distinct contrast to the Imperial War Museum's World War I and II Galleries and with the prominently visible and awe-inspiring displays of war weaponry which greet visitors in the Museum's Atrium.

I shall argue that, as part of forging this 'special identity', design choices have played an important part. Exhibition architect Stephen Greenberg and designer Bob Baxter developed a 'documentary-style approach' intended to lead visitors to a form of elucidation of the historical past. The intention of the curators was to ensure that 'irrefutable historical evidence is placed before the visitor' (Bardgett 1998: 37). The exhibition is heavily reliant on visual material - predominantly on contemporaneous historic photographs, film footage, and on survivor testimonies. The latter have been collected by Annie Dodds for this exhibition. Although sparse, authentic artefacts effectively document key events, the perpetrators' actions, and the Jewish experience through all stages of persecution, mass extermination, hiding and liberation. Artefacts and video testimonies, alongside historic footage, are masterfully staged to construct a historical narrative which aims to tell the story of Jewish persecution and survival in an authoritative and sombre tone. This involves a subdued design, which avoids the commonly used dramatization by means of 'sights, sounds and smells' (Bardgett 2004: 154). Baxter explains that the exhibition never intended to 'reconstruct' the Holocaust through a 'film set' type scenery (cited in Stiles 2016: 68). Design is intended to inform and should not impress, as Bardgett explained '[it] should not involve pretence or reconstructions, as its prime duty was to inform visitors of what happened rather than tell them how to feel, and a straightforward, uncomplicated treatment would serve the subject best' (Bardgett 2004: 154). Instead, the content of the exhibition would speak for itself: 'The story of what happened - and the artefacts and other evidence which document it - should stand on their own and should need little in terms of support' (Bardgett, cited in Holtschneider 2011: 155). Hence, the intention of the curatorial team is to frame content in a minimalist manner which foregrounds historical sources and avoids using pronounced design elements. Design should support the narrative and refrain from drawing attention to itself. The exhibition narrative and design were to create an engaging, yet 'solemn' space (Bardgett, cited in Holtschneider 2011: 155).

While these intentions find expression in the exhibition's understated design choices, even if minimally used, this research study seeks to show that such choices had significant bearing on visitors. Although the exhibition does not intend to 'tell visitors how to feel' (Bardgett 2004: 154) or to impact on the visitor's emotional involvement, I argue that the design choices triggered emotional responses, and also inevitably impacted on visitors' understanding of content, and should therefore be subjected to a deeper scholarly examination.

\section{A brief account of the Holocaust Exhibition's key design elements}

The exhibition opens with an introductory semi-circular space conceived as 'a space for visitors to be settled and given some sense of the gravity of what lay ahead', and ends with a similarly designed space meant to 'allow the visitor time to reflect before leaving' (Bardgett 2004: 155). The historical narrative is linear and chronological, divided into clearly signposted chapters beginning with the aftermath of World War I and ending in 1945 with the liberation of Bergen-Belsen by British troops. The exhibition space of 1,200 square metres is organized on two levels which divide the historical narrative into two main sections: the first level deals with the period between 1933 and 1938 and the lower floor of the exhibition represents the years after the Nazi invasion of Poland until the end of World War II in 1945. The historical narrative is primarily based on a wide range of visual materials, particularly of historic photographs, audio-visual recordings, material artefacts belonging to victimized 
groups and to perpetrators. It incorporates an impressive number of audio-visual survivor testimonies, which give a compelling account about each chapter in the development of the war and of the Holocaust. For Suzanne Bardgett, testimony plays a key role: the survivors' memories perform 'an important function in humanising the narrative' (cited in Kushner 2001: 90-1). I agree with Tony Kushner's observation that testimony 'is so skilfully and smoothly presented that there is rarely any dissonance either within the different voices of the survivors or between their collective testimony and the rest of the exhibition. [...] At each stage there is testimony that is rich in power and emotion' (Kushner 2001: 91). The latter is confirmed by the students participating in this study. For them, testimonies and items belonging to the victims have triggered the most powerful emotional reactions. The curatorial intention to 'humanize' the experience of the survivors is reflected in the students' reactions. Most thought that testimonies facilitate a 'connection' with the survivors. This is reflected in comments such as: 'The testimonies bring you closer in terms of engagement; listening brings lots of attention', and 'Made me connect with the people and understand how they must have felt going through it'. Testimonies enabled students to perceive this history in more intense and vivid ways (represented by comments such as 'Very powerful as they came from real people rather than "facts"', 'Made the experience feel a lot more real', 'Offered extra insight').

Aside from testimonies, several design elements dominate the mis-en-scene of the historical narrative. Light, dark space, and sound underline the stages in the historical development of the Holocaust. In the exhibition's first chapter, 'Life before the Nazis', the normality of everyday life is conveyed by means of light-coloured wood panels, in conjunction with content such as upbeat Klezmer songs, witnesses' accounts of their pre-war lives, and photographs depicting family gatherings and individual portraits. The sense of everyday life is then quickly broken by the sounds of shootings and footage of aircrafts in flight displayed against a black wall. An introductory text panel provides a thorough definition of the Holocaust and prepares the visitor to discover 'how and why these things happened'. From here on, visitors work their way through the chronological narrative organized into chapters, beginning with Europe after World War I, and continuing with the rise of Adolf Hitler and the coming to power of the Nazis. This is followed by a chapter on Antisemitism defined as 'the longest hatred', the creation of the racial state and its pursuit of racial purity, and the exclusion of groups defined as 'outcasts', leading to a chapter on the annexation of Austria and the Jewish refugee crisis. This part of the exhibition is dominated by artefacts produced by or belonging to the perpetrators including uniforms, insignia, a wide range of Nazi propaganda publications, posters, leaflets, pamphlets, films, and recordings of speeches. The upper floor ends with a chapter on Kristallnacht and on the T4 programme. The key artefact which dominates this part of the exhibition is a replica dissection table modelled on the original marble table from the Kaufbeuren-Irsee psychiatric hospital in Swabia on which experiments were conducted on disabled and mentally ill individuals including children.

The bright white table is placed against a black wall on which three large-sized photographs depicting naked children crying and in great distress stand out. The pain and suffering of the children are further amplified by means of design. The well-lit enlarged photographs stand out against the black wall. The white bodies of the children pictured in the photographs resonate with the sterile whiteness of the dissection table. This 'deeply disturbing object' explained Bardgett, 'provide[ed] exactly the right physical and historical 'crisis point' between the exhibition's two floors' (Bardgett 2004: 156). It signified the transition from discrimination and exclusion to murder (Holtschneider 2011: 91). The staging of this artefact in relation to the photographic displays and the chosen colour scheme are devised to inaugurate the visitor's experience of the lower floor with an unavoidable affective jolt. This arrangement reflects Bardgett's and the curatorial team's vision that each item on display 'would support the narrative above all, history would take priority over design'. It 'would produce an exhibition in which the visitor interacted directly with the raw historical evidence' (cited in Stiles 2016: 78). This interaction is indeed encouraged by the audio guide, which draws attention to various key artefacts.

The lower floor is significantly darker and is dominated by the voices of survivors. The audio guide makes students aware of the sombre tone of this section. It describes spaces as 'dark'. For example, in the section 'Euthanasia', a male voice tells the visitor: 'Turn your back 


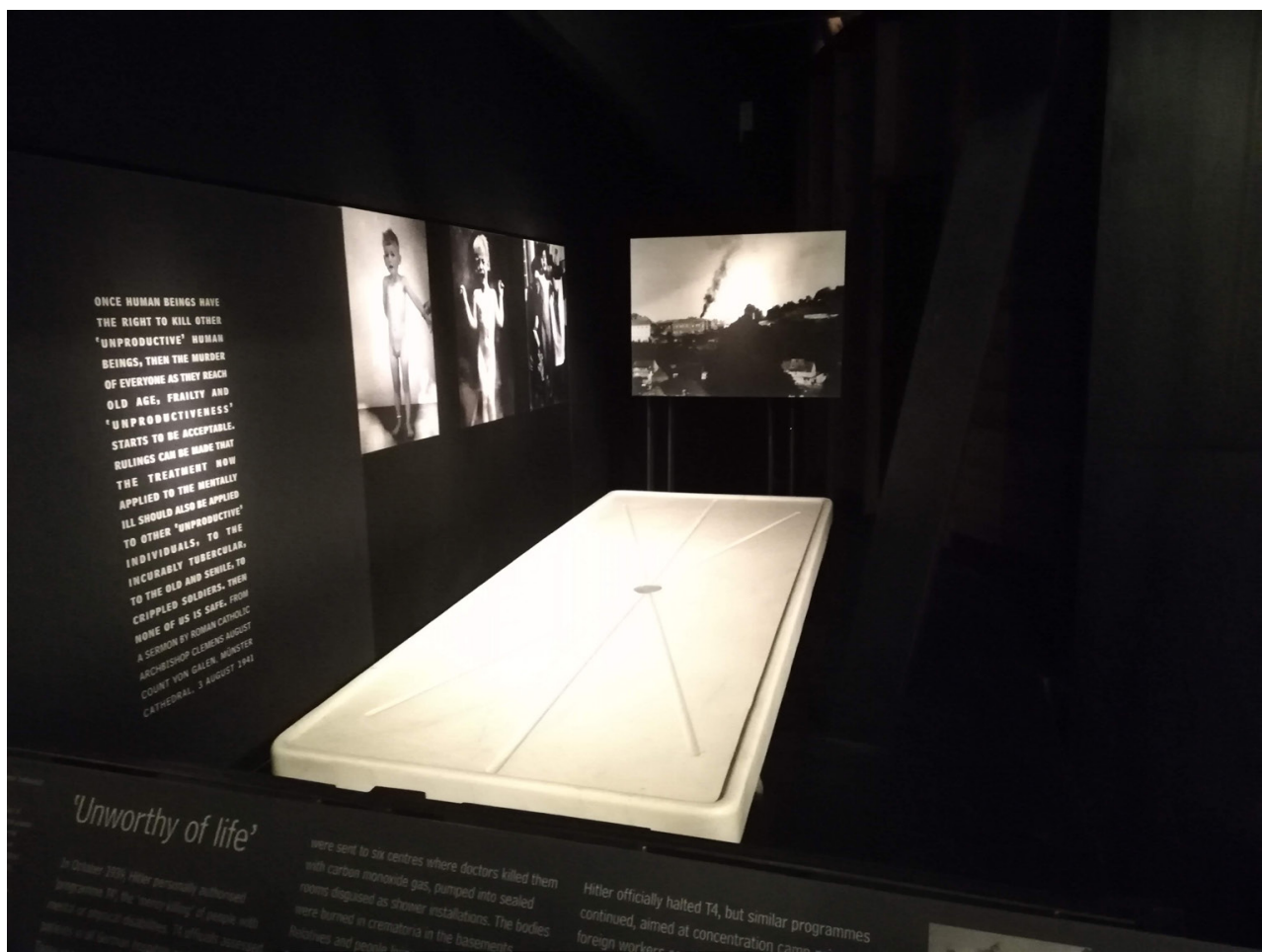

Fig. 1. The marble table from the Kaufbeuren-Irsee psychiatric hospital, photo taken by Diana Popescu, courtesy of the Imperial War Museum

to the brown map and walk ahead towards the stairs. On the left is a small dark space. In it is a dissecting table' (Imperial War Museum and Kharibian 2009: 19). It even symbolically associates lighting with the subject matter. In the display dealing with Einsatzgruppen II visitors are told: 'Now continue on to the right and round the partition into the next space. It's very dark - as it marks the Nazi destruction of an entire way of life' (Imperial War Museum and Kharibian 2009: 26).

In the lower floor of the exhibition, the focus shifts also to larger photographic displays which, alongside text panels, document the Nazi invasion of Poland, the persecution of Polish Jews, the collaboration of local populations in the persecution of Jews and the horrors of the Eastern Front known as 'the Holocaust by Bullets'. Like the dissection table, another disturbing item is the cattle truck which marks the transition from deportation to mass murder. This artefact leads to a chapter on the Auschwitz camp system. This space is dominated by a well-lit twelve-metre-long and two-metre-wide white model of Auschwitz-Birkenau. The model, designed by artist Gerry Judah, depicts the arrival of 2,000 Hungarian Jews during the last deportations to Auschwitz in May 1944.

In the audio guide the model is described as 'a huge white scale model'. 'PAUSE It shows the point of arrival at Auschwitz-Birkenau, the biggest of the Nazi death camps and it reconstructs the last moments of 2,000 Jews arriving from Hungary in late May 1944'. With this choice of words, the relationship between design and content matter is established: size corresponds with the scale of the death - the 'biggest of the Nazi death camps'. Students are further informed about the historical accuracy of the model, 'the model-makers have been able to be so precise because of an extremely rare set of photographs' (Imperial War Museum and Kharibian 2009: 38).

Two large photographic displays frame the model: at one end of the model an enlarged photograph depicting the arrival at the site symbolized by the infamous Gates of Auschwitz, and at the other end, a photograph display depicting the ovens of the crematoria. On the lefthand side of the model there is a row of dimly lit chairs separated by black panels. 


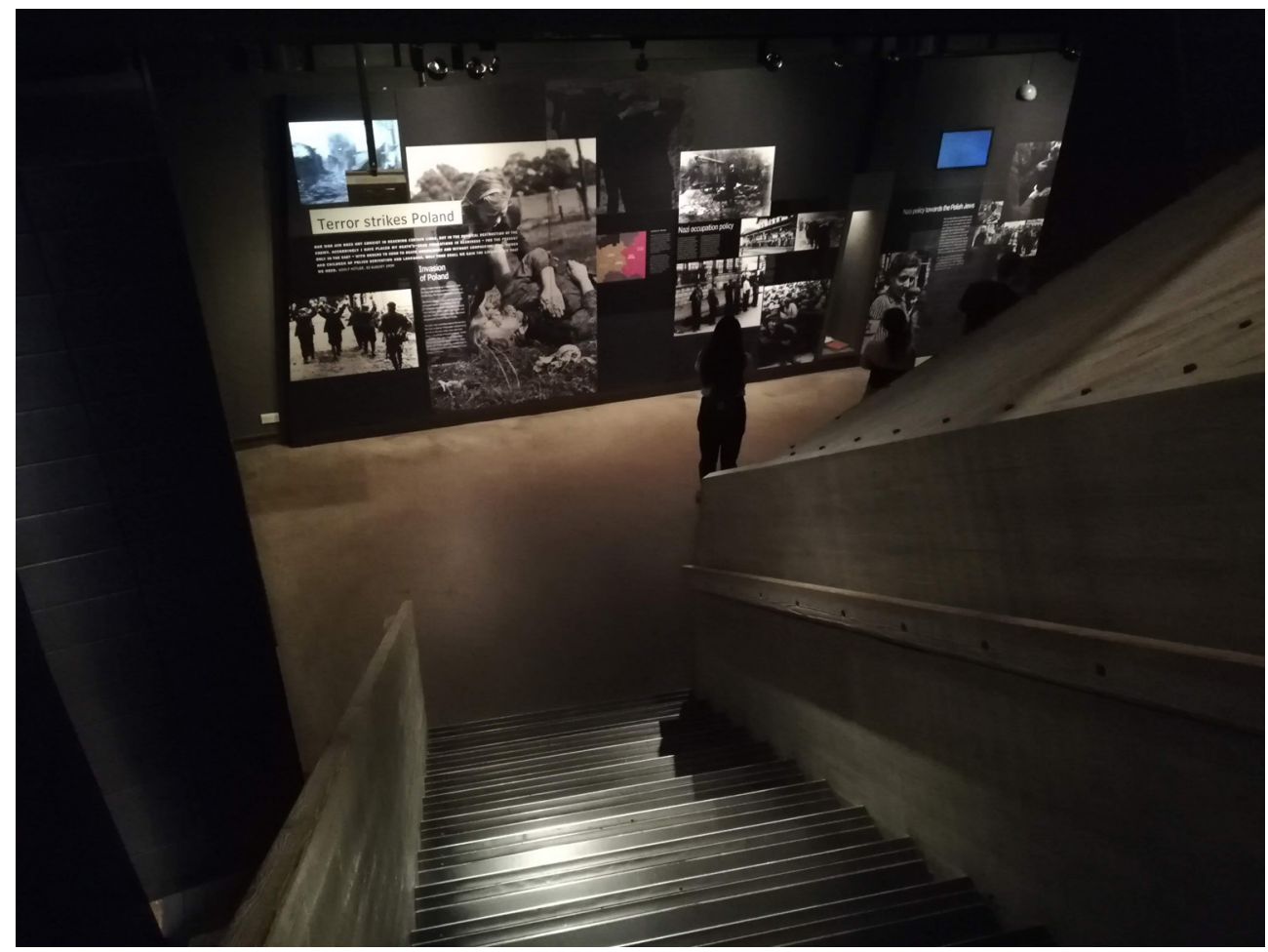

Fig. 2. The descent into the Exhibition's lower floor, photo taken by Diana Popescu, courtesy of the Imperial War Museum

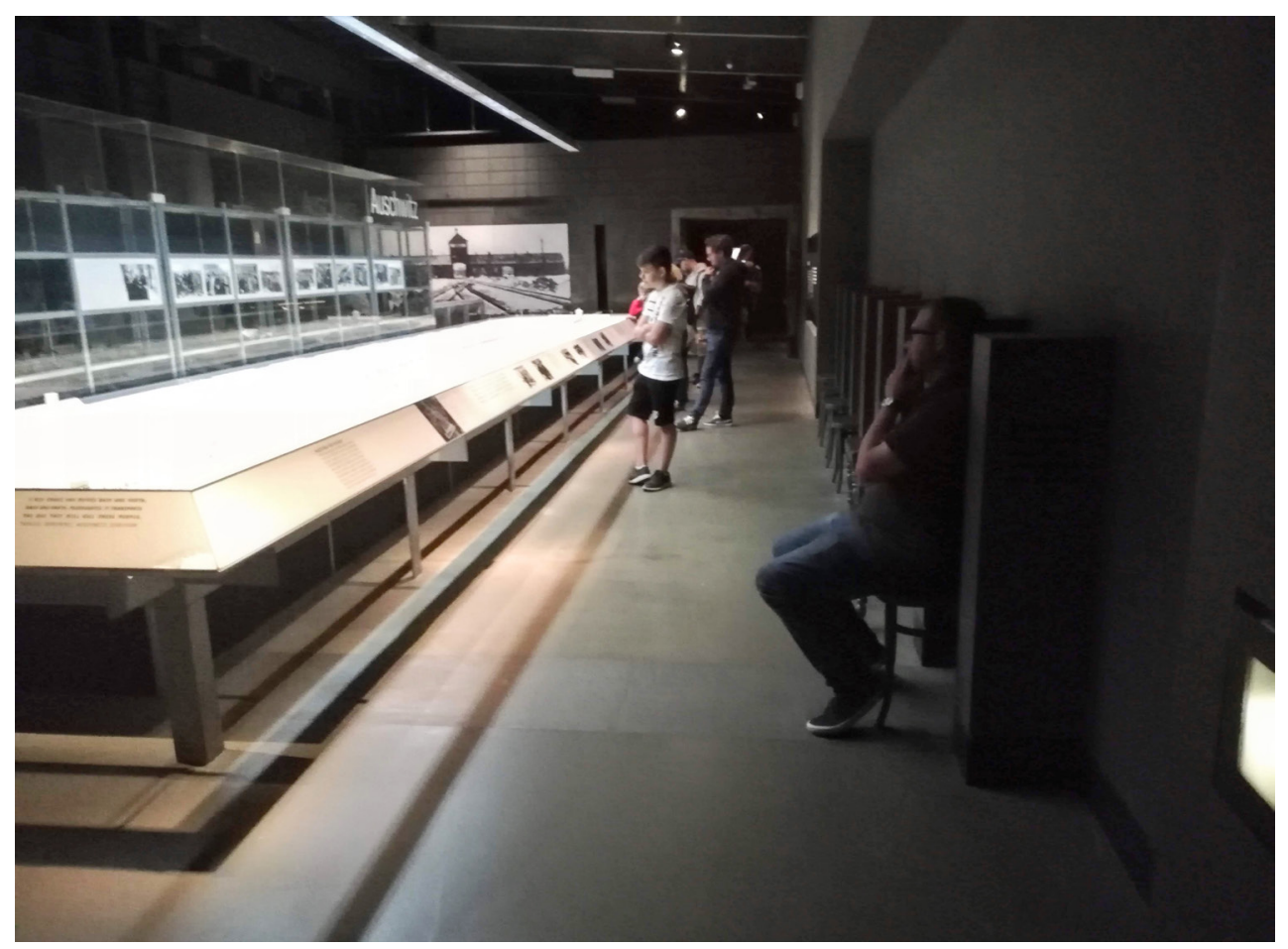

Fig. 3 Auschwitz model, photo taken by Diana Popescu, courtesy of the Imperial War Museum 


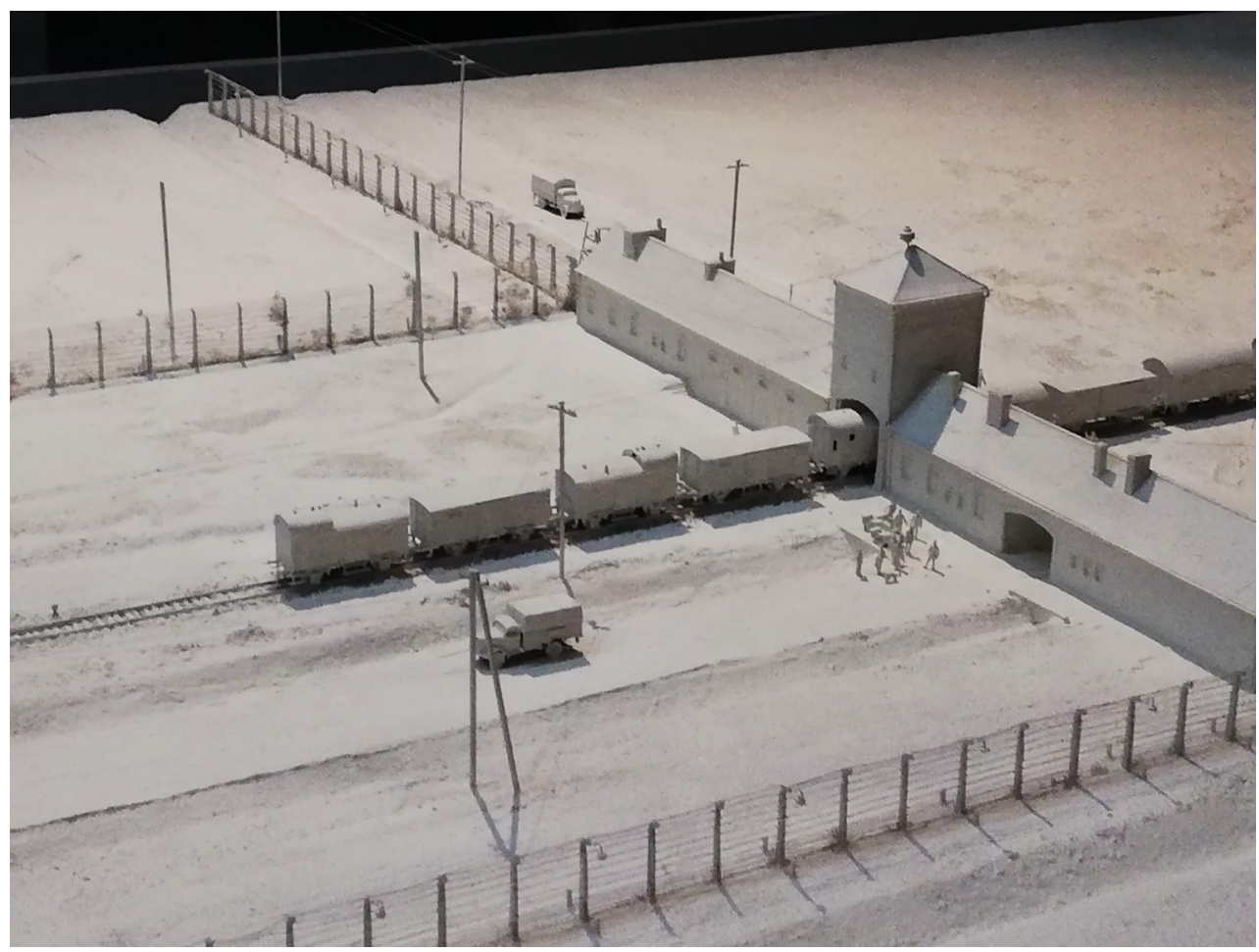

Fig. 4 Auschwitz model, detail, photo taken by Diana Popescu, courtesy of the Imperial War Museum

Visitors are encouraged to take a seat and to listen to survivors' testimonies, which can be heard through headphones installed on each side of the chairs. Enveloped in darkness, visitors are invited to examine the model, which depicts in detail, the arrival, selection, and extermination taking place in Auschwitz.

In the absence of photographic representations of the arrival of the victims, this model enables an appreciation of the scale of the extermination operations taking place daily on the site. As visitors leave the model, they turn right into a space housing the shoes of victims protected by glass cases, which are lit from light filtering through the model. Several design choices encourage a nuanced engagement with this space. On the one hand, the well-lit model symbolically positions viewers at an emotional distance, inviting them to examine in close detail the mechanisms which facilitated mass murder. On the other, the softly lit shoes convey a commemorative mood and encourage visitors to think about the owners and to reflect on their absence.

The space becomes brighter in the last sections of the exhibition which document the reactions of the Allies, rescue efforts, survival by hiding, the discovery of the crimes and the liberation of Bergen-Belsen by the British army. The last chapter of the exhibition space informs about the fate of the murderers and the Nuremberg Trials. Then, the visitors enter an open space where they can take a seat on chairs, and view at their own pace, video recordings of survivors. The visitors are by now familiar with the survivors whose names, faces and voices they have encountered throughout the exhibition space. A sense of distance from the Holocaust is conveyed by survivors who give account of the many ways in which their lives have been indelibly scarred by the events they have witnessed.

Closed or open spaces in the Holocaust Exhibition elicit different responses. Semicircle or circular spaces combining spaciousness and light can serve to make visitors feel unbound, while narrow spaces create a sense of confinement, claustrophobia, fear or panic at its worst (Stenglin 2004). 
Walking through the cattle truck used to transport victims to death camps is meant to create a visceral response. The audio guide encourages this response, anticipating the sensations visitors might experience: 'Running down the left side is part of a cattle-truck. You can go over and feel it [my emphasis]' (Imperial War Museum and Kharibian 2009: 37). This framing, as Alison Landsberg argues elsewhere, 'complements the cognitive [mode of engagement with the Holocaust in museums] with affect, sensuousness and tactility' (Landsberg 2004: 131). Spatial layout can direct visitors' focus to specific displays. On the lower floor of the Holocaust Exhibition, as visitors descend the staircase, their attention is directed to the busy visual displays located to the left-hand side documenting the main stages of the Nazi invasion. They pay less attention to the panels found to their right-hand side, which document among others Britain's reactions to the Nazi invasion of Europe.

Other elements of design such as interactive displays are used sparsely and exclusively for purposes of transmitting historical information. Visitors can listen, via phone receivers, to recordings relating experiences of refugees in Britain (e.g. German Jewish refugee Henry Fulda) giving account of confinement on the Isle of Man as 'enemy aliens', or a speech by the Archbishop of Canterbury on the refugee crisis. On five touch screen computers equipped with benches, visitors can access information about all persecuted groups, European countries' Jewish populations, and those countries' distinct positions in relation to Nazi Germany. They can find answers to commonly asked questions such as why the Allied countries did not intervene to stop genocide by bombing the rail tracks leading to Auschwitz.

The Holocaust Exhibition also includes several seating areas used to facilitate visitors' focus on video-audio recordings of survivor testimonies, or information about Antisemitism, conditions in the Auschwitz camp, and video footage of the liberation of BergenBelsen. During my visits I found some seating areas encourage visitors to perform behaviours reminiscent of those performed by historical subjects. In the alcove devoted to the Nuremberg Laws, a wallpaper reproduces sections of the laws, and includes an image of a park bench marked 'nur für Juden' (Jews only).

A bench resembling the one in the picture is placed in the foreground albeit without this inscription. It invites visitors to take a seat and to view a video testimony in which survivors give account of the impact of the laws on their lives in Germany. It should be noted that on several occasions, this bench generated confusion among some visitors since they were unsure as to whether they should take a seat or not. Despite this issue, the bench still effectively challenges the visitor to think about their personal relationship with this history. How might they have reacted to and been affected by such laws?

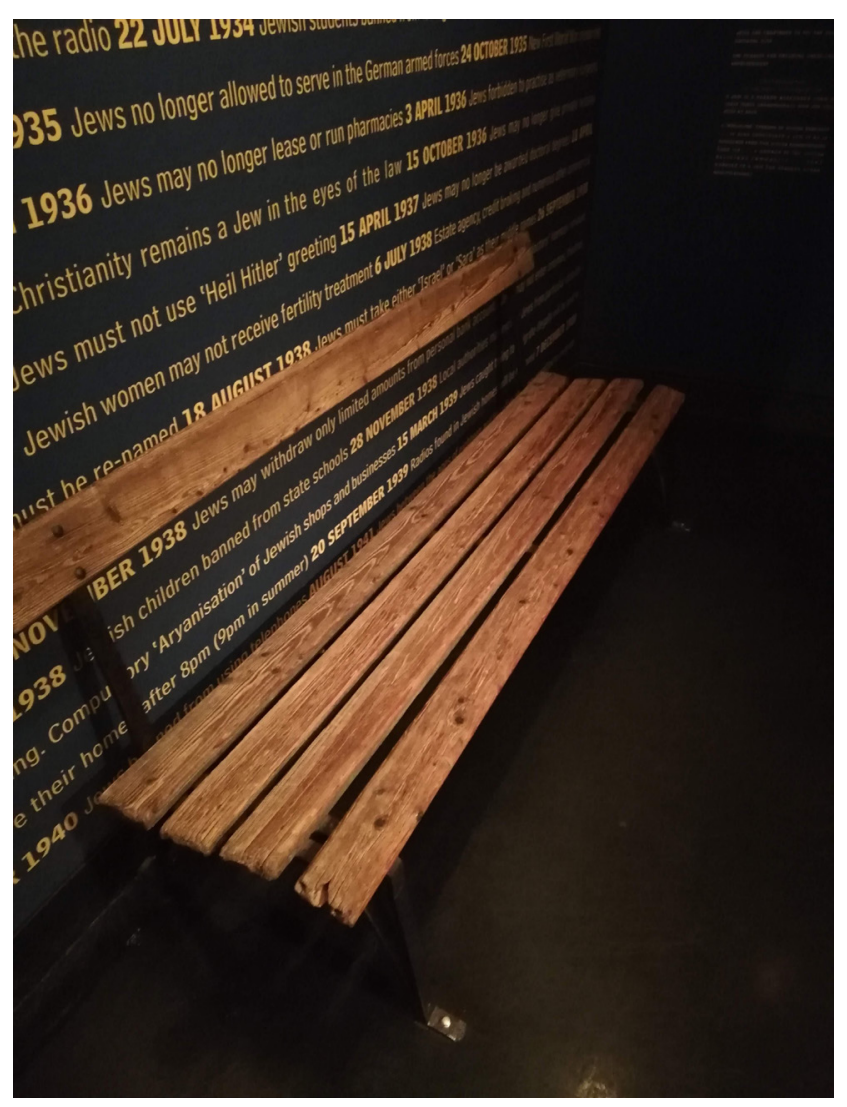

Fig. 5. The bench resembling a real park bench in Germany during the Nuremberg Laws, photo taken by Diana Popescu, courtesy of the Imperial War Museum 
It should be stated that not all elements of design will be noticed by all visitors, nor will visitors perceive them in the same way. However, the participants in this research study were receptive to the afore-mentioned elements of design and, as I shall show in the following sections, were able to articulate their impact in persuasive ways.

\section{Research study}

Young people are among the core audience group of the exhibition. Each academic year over 21,000 school students from Year 9 to Year 13 visit the Holocaust Exhibition. School groups are invited to take part in a 30-minute orientation session which introduces them to the exhibition through artefacts, replicas, art and personal stories. The groups then take an audio-guided tour of the exhibition. At the end of the tour they participate in a 25-minute debrief session, share impressions of the exhibition, and reflect on its meaning. With the support of the Holocaust Exhibition's Learning Manager, Rachel Donnelly, I conducted a cross-sectional survey study with two groups of A level students from England and Scotland (40 young people between 16 and 18 years old). Although they reported to have studied the Holocaust in school, a short survey conducted at the beginning of the research session, and later confirmed by their responses, revealed that the groups had a limited subject knowledge. Pupils spent up to two hours visiting the Holocaust Galleries and took an audio-guided tour. The audio guide provides a sound introduction and an opportunity to learn and engage with this history by drawing attention to various artefacts on display. Importantly, it encourages listeners to reflect on questions and, in this manner, engage actively with the historical material. For instance, it asks questions relating to human behaviour: when Esther [Brunstein, survivor] talks about the Poles who took a spontaneous part in the persecution of a Jewish man she saw in the street, the audio guide asks 'How should we judge them? Does knowing that they were also terrorised by the Nazis make a difference?' (Imperial War Museum and Kharibian 2009: 22).

When visitors arrive at historical photographs depicting the Jews in the Warsaw ghetto, the audio guide makes them aware of the biased nature of these sources. It encourages viewers to take a critical distance from the exhibition's historical emplotment and to reflect on ethical questions: 'Most of the visual evidence we have for the Holocaust was made by Nazis for other Nazis to look at. We are seeing the victims through the eyes of their persecutors. Knowing this, do you think pictures like these shouldn't be displayed? Or do you think it's more important that the truth of what the Nazis did to innocent people be seen - whatever the origins of the image? PAUSE [this pause allows students time to reflect on this question] One thing is certain, the mind-set of the men who took these photos left its mark on the way they chose and framed each particular scene. This evidence, therefore, is not neutral' (Imperial War Museum and Kharibian 2009: 28).

In the section on the inhuman conditions in the ghettoes, the audio guide asks students: 'Why do you think the Nazi authorities were so adamant children shouldn't go to school? And why, when things were so bad, and the future looked so uncertain, do you think people were still so eager to learn?' (Imperial War Museum and Kharibian 2009: 29). As seen from these examples, the museum promotes a learning experience described by Rachel Donnelly as 'aim[ing] to encourage students and their teachers to embrace the complexity of this historical process and challenge misconceptions about the Holocaust found in wider culture which they might bring to the museum' (Donnelly 2018 para. 25). The audio guide stimulates young people to think about such complexities. It ends by raising the question of responsibility in the face of such atrocities:

But as we've seen today, the Holocaust didn't happen simply as the result of Hitler's will; the net of responsibility is far wider than that. The Holocaust took place because individuals, groups and nations made decisions to act or not to act. It is only by focussing on these decisions, in all their complexity, that we may gain an insight into the history of the Holocaust and into human nature itself (Imperial War Museum and Kharibian 2009: 51).

The final comment leading to the closing display encourages silent reflection: 'To finish, turn and go into the space with the blue carpet. If you like, take a seat and listen to survivors talking 
about their feelings today, or spend some time quietly. Wait there for your teacher before leaving' (Imperial War Museum and Kharibian 2009: 51). As illustrated here, young people are addressed as active learners prompted to learn, to think critically about this history with the support of artefacts and primary sources, to question the biased nature of sources, and finally to reflect on what this history tells about human behaviour.

Further reflection was also encouraged by the survey I invited the students to complete after their audio-guide tour ended. This included 30 open-ended and close-ended questions, as well as rating and multiple-choice questions. The analysis of the survey involved coding responses into sub-themes, followed by identification and categorization of sub-themes into broader thematic categories using NVivo, a qualitative research software used in the humanities and social sciences. Part of the survey questions aimed to learn more about how participants perceive the effects of specific design elements. The participants were offered a definition of design as 'the arrangement of objects and material artefacts in space, the use of light or of darkness, the use of sound, the physical layout of the exhibition space, any devices or objects visitors are encouraged to physically interact with'. The survey included the following questions:

Please explain whether and how the following elements of the exhibition's design have affected your experience:

- The use of lighting in the exhibition space (e.g. well-lit or dark spaces)

- The spatial layout of the exhibition (e.g. the size of the exhibition rooms, the paths visitors are invited to follow)

- The presentation of objects in space (e.g. objects under glass cases, objects you can view at close range or at a distance)

- Interactive displays (e.g. invitations to touch exhibits, open boxes, rest on benches/ chairs)

Did the exhibition design enhance your ability to remain focused on the historical information being presented? Please explain how.

Did other visitors' behaviours affect your experience of the visit? Please explain how.

Much in the same vein as the audio guide, these questions appeal to young people's critical capacity and demand distance from the exhibition. By asking questions relating to design rather than the content of the exhibition students are prompted to think differently about the meaning of museum exhibition as a 'construct'. They are introduced to the idea that exhibitions are the product of a process of research, and selection of historical sources and re-presentation of sources in a museum space.

The following section presents responses to the above questions and represents the students' first attempts to think reflectively about aspects of exhibition design. I have organized their comments into themes which emerged as I developed a qualitative analysis of the data. The identified themes are introduced in the headings of the sub-sections below. I then provide examples of the most relevant comments illustrating these themes. To recap, the producers of the exhibition intended that design remains in the background and gently supports the historical narrative constructed through historical evidence. It emerged that this does not necessarily reflect the participants' experience of the exhibition. More than a supportive role, design choices shaped the participants' emotional response and influenced their learning experience. I document these impacts in the next section and illustrate with examples how students respond to each design element. Later, I discuss these findings and their implications for exhibition designers in greater depth. 


\section{The Impact of Lighting (well-lit versus dark space)}

As stated earlier, dark space is a dominant feature of design. The audio guide directs students through space by describing spaces in terms of colour, size and mood. The term 'dark' is used in the audio guide in relation to the euthanasia programme and as a context for displaying difficult to view artefacts (e.g. the dissecting table), in connection to the mass shooting on the Eastern front committed by Einsatzgruppen: 'It's very dark - as it marks the Nazi destruction of an entire way of life' (Imperial War Museum and Kharibian 2009: 26) and to deportations: 'Now move into the next dark space. Running down the left side is part of a cattle-truck. You can go over and feel it', as well as to life inside the camps: 'Few inmates had the opportunity to resist or escape. Turn now so that your back is to the photos. Move ahead, past some striped clothes on the left, and turn left into the next, dark, space' (Imperial War Museum and Kharibian 2009: 44). These practical instructions guide the students through space but also encourage thinking about the subject in connection to the meaning of lighting.

Most participants (x23) responded positively to the use of lighting, although some had mixed feelings (x12), and a small number (x3) made critical comments. The majority thought that lighting was appropriately used and in resonance with the subject matter. As they are encouraged by the guide, they noticed the presence of 'darkness' or of 'dark spaces', and observed the contrast obtained by the juxtaposition of dark and well-lit space, as for example: 'The lighting of the Auschwitz model was particularly effective'.

Dark space was understood to impact in a variety of ways as noted in the thematic nodes illustrated with examples below.

\section{Theme 1. Creating an (Affective) Commemorative Mood}

There is a sense that dimly lit panels and dark space are an appropriate way to approach the subject matter. This approach is encouraged by wording used in the audio guide, as exemplified above. In line with such descriptions, students realize that dark space is an effective tool used to create what they describe as a mood/atmosphere.

'atmosphere' or 'experience'

'adding to the atmosphere'

'setting the correct mood'

'effective', and 'affective'

'reflecting the mood'

creating an 'eerie atmosphere'

making one feel 'immersed'

'fitting the mood and atmosphere of the subject matter'

'good/powerful'.

For other visitors, darkness created affective spaces, noting for example that it:

'adds to an emotional experience'

makes one feel 'nervous', or 'concentrated'

creates a sense of 'gloom', or 'feeling sad'.

Others mentioned it helped them to:

'feel calm and relaxed'

'the dark was very calm and allowed for a peaceful and respectful atmosphere ideal for reflecting'

'the darkness created a calming and respectful environment'

'dark atmosphere sombre mood, appropriate as reflecting and learning about the Holocaust is particularly saddening'.

These comments reflect a commemorative understanding, facilitated using dark space. This was certainly not the main intention of the exhibition producers. Bardgett did not plan to include 'a memorial element, since this would be at odds with the general purpose of the museum, which is to educate rather than to commemorate' (cited in Pearce 2014: 119). She did however recognize the need for a reflective space and stated this would be incorporated 
into the final design (cited in Donnelly 2018: para. 12). Furthermore, Donnelly recognizes 'the exhibition's memorial element is more obvious. The use of dark colours throughout and low lighting - partly due to the needs of conservation - reflect the seriousness of the subject, but also encourage a sense of reverence similar to that of a memorial space' (Donnelly 2018: para. 13). Despite its educational purpose, visitors' reactions to the exhibition show that design can produce an unanticipated memorial effect. The audio guide contributed to further reinforcing this perception. These responses convey the importance of design choices and the need to consider, based on visitors' experience, how design frames and affects visitors' understanding of the Holocaust.

This study shows that the exhibition is predominantly interpreted as a memorial space, where one feels sadness for the loss of life, and shows respect towards the victims. This perception is amplified by survivor testimonies giving account of each stage of the process of exclusion, persecution, and extermination. When a commemorative perception prevails, visitors are likely to act as agents of memory rather than as critical learners. While memorialization does not exclude learning, by its very nature, remembering is a selective and a subjective process. This means that certain aspects of the historical narrative may be remembered while others are not. In contrast, a pedagogical mode is about asking critical questions. When achieved successfully, this can lead to a transformative encounter experienced on many levels: intellectual, emotional, and spiritual. I do not imply that design elements do not encourage critical interpretation of historical knowledge. However, in view of current insights emerging from the research study conducted by the UCL Centre for Holocaust Education, students in Britain are less likely to engage in such an interpretation, given their limited knowledge and understanding of the Holocaust (Foster et al. 2016). Students participating in this survey also displayed a low level of subject knowledge. Their exposure to the subject came from history lessons, talks given by a Holocaust survivor, or presentations from other classmates who visited Auschwitz. Students' knowledge of the subject was shaped by films such as La Vita è Bella, The Boy in the Striped Pyjamas, or I am David. A few students noted having a family connection or having taken a personal interest in the subject. Most students were on their first visit to the exhibition (x32) and perceived the visit as a school assignment (x24), while only 12 students recognized the Holocaust Exhibition as being the main purpose of their visit. In the absence of sound historical knowledge, the memorializing of the Holocaust may prove to be weak, no matter how well designed the exhibition may be. Hence, design elements such as dark space, which facilitate a commemorative experience, should be used more sparingly within the educational context of a historical exhibition.

The Imperial War Museum's Holocaust Exhibition was primarily designed with educational aims in mind. As Bardgett states, it did not intend to have a memorial element as 'it would be at odds with the general purpose of the museum, which is to educate rather than to commemorate' (Bardgett, cited in Pearce 2014: 119). However, visitors' reactions, documented in this study, show that design can produce an unanticipated memorial effect. This conveys the importance of design choices and the need to consider, based on visitors' experience, how design frames and affects visitors' understanding of the Holocaust. Aside from this prevalent association, other consequences of lighting relate to how it allows or obstructs access to the information in text panels. The following are several consequences of the use of lighting which the curators did not intend to produce. Students reported several unexpected and dissonant reactions to the usage of dark space: it invited them to read the text panels which are well lit, and it directed their attention to artefacts such as the dissecting table, or the Auschwitz model. Evidently, this usage of light worked to hide or obscure other exhibits or text panels.

\section{Theme 2. Channelling attention and impacting on learning}

Therefore, not all participants in the study observed the commemorative mood rendered through lighting. Instead, many noted how it worked to direct their attention and encourage them to focus on certain spaces, text panels or items. Well-lit panels were interpreted by students as delivering key messages from the exhibition's content. This understanding is illustrated in comments such as: 
'directs attention to parts of exhibition'

'enhances focus on specific aspects of the exhibition, or objects'

'made me focus more such as when something was really lit up'

'allowed me to focus on reading important things'

'made you focus more on the exhibits'

'It was dark; however, the reading parts had lights onto them, making it easier to focus'.

The Auschwitz model was deemed to be the focal point of the exhibition space. Rachel Donnelly is aware of this perception among its visitors: 'for many visitors it is undoubtedly one of the most memorable aspects of the exhibition' (Donnelly 2018: para. 17). Aspects of design contribute towards this perception. The model is positioned toward the end of the exhibition, is very well lit, and occupies a significant space. Chairs placed on its side further convey to visitors that it is worth spending more time in this space. The whiteness of the model, coupled with it being well-lit, act to convey the message that Auschwitz is a key event of the Holocaust which deserved most attention. This message was somewhat intended by the designers who were mindful of the importance of this climactic moment of the historical narrative. Donnelly further explains that the 'focus on Auschwitz was clearly influenced by research published in the 1990s about the camp's significance within the Holocaust' (Donnelly 2018: para. 18). Unlike other death or concentration camps, Auschwitz is discussed in most detail. Its centrality is reinforced by the dominant testimonies of Auschwitz survivors. The audio guide focuses on this site of destruction to the detriment of other sites. Names of death camps, and other murder sites such as Treblinka, Sobibor, and Chelmo are only briefly mentioned. This perception is not conveyed by design alone, but is shaped by social and cultural factors external to the exhibition. Auschwitz visually dominates global popular culture (in films), and its status in reinforced by early commemorative events which nearly always include images of the infamous Gates of Auschwitz, of crematoria or of rail tracks leading to the camp. In Britain, as demonstrated by the programme 'Lessons from Auschwitz', run annually by the Holocaust Educational Trust, Auschwitz is the key destination for school groups interested in learning about the Holocaust. ${ }^{2}$ The UCL Centre for Holocaust Education's research into British students' understandings of the Holocaust, confirmed by The Imperial War Museum's unpublished research conducted by Muse (2016), shows that 98 per cent of people surveyed chose 'Auschwitz' as the camp most commonly associated with the Holocaust (Donnelly 2018). The exhibition reinforces this common perception which leads to a narrow, if not skewed understanding of history. Importantly, the new Holocaust and Second World War Exhibition led by James Bulgin will no longer focus on Auschwitz alone, and the model is unlikely to feature in this exhibition. As Donnelly (2018, para. 42) reports, 'Bulgin's intention is to decentralise the status of gas chambers in popular understanding, acknowledging the 'Holocaust by bullets', starvation and 'annihilation through work' as being profoundly significant aspects of the Holocaust alongside the death camps'.

This research study reveals that visitors are indeed sensitive to design choices, particularly when these are mirrored by popular understandings of the Holocaust. The participants' responses reveal that lighting dictates which moments in the historical narrative are of more relevance or of more importance. Spot-lit objects surrounded by darkness eliminate other elements from the visual field, channel the visitor's attention and minimize distraction. They can help deliver the learning objectives of the exhibition's educational programmes and help to minimize visitor fatigue. Given the typical abundance of text panels and of objects in display cases, lighting makes it easier for visitors to focus on the most important text panels and objects. However, selective channelling can have its problems too, as when it inadvertently interferes with the pedagogical intentions of exhibition producers. Therefore, decisions regarding lighting as a tool for channelling visitors' attention need to be informed by visitor studies before being implemented in exhibition spaces.

\section{Theme 3. Shaping understanding of the Holocaust}

Participants noted the powerful illustrative and symbolic usage of lighting. Lighting was interpreted as symbolic of a specific aspect of the historical times. The dark environment of 
the exhibition space, or the presence of the colour black were deemed to represent 'the evil' and 'the horrors of the Holocaust'. This was reinforced by the usage of the word 'dark' in the audio guide, in connection to the destruction of Jewish life. Encouraged by these associations, participants in this study developed other symbolic associations between colour and symbolic meaning. For example, the colour red was linked to the violence of the Nazi regime.

'the darkness in many areas helped to demonstrate the horrors of the Holocaust' 'making it darker showed that this was a dark time for humanity'

'the use of dark and red lighting when describing Hitler's invasion of Poland as it symbolized the death and suffering people went through'

'[dark space] would make me subconsciously relate the Holocaust to darkness and evil, thus improving my experience'.

These reactions convey a process of 'conceptual broadening' (Roppola 2012) whereby visitors draw a cognitive and moral message from the usage of design elements. Design shows something about the historical times without having to explain it to visitors by means of textual media. The result is that visitors 'fill in the dots'. A moral message is inherent to the usage of dark space. It implies that traumatic histories cannot be fully known or understood, and the visitor should acknowledge this limitation and approach this history with quasi-religious reverence. This moral message is encoded in the fabric of many memorial exhibitions. Such a curatorial approach was influenced by survivors, especially Elie Wiesel, who played an influential role in linking the Holocaust with darkness and mystery. He famously stated in a New York Times op-ed, in relation to Holocaust representation in the NBC TV series The Holocaust in 1978: '[t]he Holocaust [is] the ultimate event, the ultimate mystery, never to be comprehended or transmitted. Only those who were there know what it was; the others will never know' (Wiesel 1978). Encoded in Wiesel's comment is a moral message to generations with no connection to the Holocaust, advising them to approach the subject with quasi-religious reverence. Such a message is further encoded in the design of Holocaust exhibitions.

It is fair to note also that moral messages are determined by numerous factors including the visitor's personal outlook and prior knowledge, as well as their social and cultural background. Most young visitors to the Imperial War Museum have listened to a survivor speak as part of their history class, or at an annual memorial event organized by their local schools. Theirs is a mediated connection facilitated by popular films such as The Boy in the Striped Pyjamas. The students' associations of perpetrators with symbolic 'evil' is not challenged by popular representations of the Holocaust. Associating the Holocaust with darkness is problematic because it strips history of real meaning. Notably, acts of extreme cruelty have happened in broad daylight, being witnessed by passers-by, by people who actively supported the persecution of Jewish neighbours. In most European countries, Jews were harassed, beaten, raped, and murdered in plain broad light. To allow students to associate such atrocious events with 'darkness' does not lead them to construct a sound moral message.

In the future Imperial War Museum exhibition the curators will include natural light, being mindful that associations with darkness are counter-productive and do not reflect the moral message intended by the curators; namely, to raise awareness of the overwhelming passivity of those who witnessed and did not act to stop such events from happening. It is hoped that the use of natural daylight in the exhibition will help visitors place this history in our [their] world. Unlike darkness, which frames this past in an unreal setting, daylight will invite visitors to think about their own responsibilities to act against similar occurrences. Such usage might also encourage analogies between past and present atrocities. BernardDonals' study of visitors at the US Holocaust Memorial Museum shows that visitors commonly make analogies between the Holocaust and other genocidal events (Bernard-Donals 2018). Analogies between past and present perpetrators or victimized groups are also likely to be made in the mind of the visitor.

Hence, design choices should be subjected to careful consideration in order to ensure that the intended message of the exhibition is not downplayed or even undermined by means of design. In some cases, the use of lighting can in fact undermine the original intentions of the exhibition makers as illustrated in the next comments. 


\section{Theme 4. Obstructing Access to Content}

For some respondents, the low level of lighting in the exhibition space obstructed access to information, making it difficult to read text panels, or to navigate the exhibition space:

'We could do with more lighting. Sometimes it was difficult to navigate'

'It was a little too dark to read some parts'

'Some parts of the exhibition were quite dark which made it hard to read certain things' 'At times it was a little bit too dark to properly read information'

'Too dark'

'I struggled to read some paragraphs with smaller writing'.

Therefore, we can see that, sometimes, certain design choices may weaken impact on the viewer, in some cases due to confusion. This last response does not align with the curators' intentions for the exhibition, hence the use of light in relation to accessibility should be very closely paid attention to.

The above-mentioned responses to this one designelement testify to the multidimensional ways in which visitors understand the impact of design, and to their acute responsiveness to it. Ultimately, their reactions confirm the vital role design plays in shaping perception and understanding of the subject matter.

\section{Spatial Layout}

Most participants in the survey reacted positively to the spatial layout of the exhibition, describing it as:

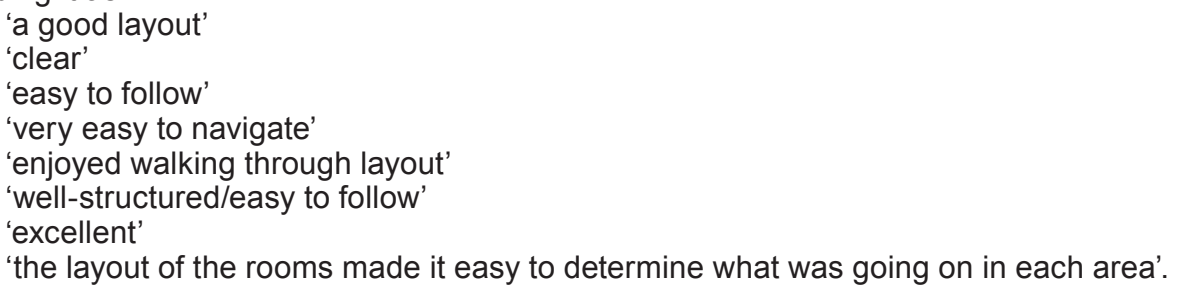

They reiterated a sense of being 'engaged', describing this engagement in terms of 'flow', as in: 'easy enough to follow, it flows well and "tells" a story'

'made sense, not all clashed together'

'good flow to follow'

'layout was good, as in there was an ongoing story without any gaps'.

For some, engagement was facilitated by the variety of sizes and shapes of the rooms, which: 'made the exhibition both interesting and engaging'

'more engrossing'.

The exhibition's layout assisted visitors to navigate and make sense of the storyline which they regarded as coherent and clear. A few remarked about the absence of information regarding the length of the exhibition, stating that 'an indication of the length of the exhibition upon entering would be good, one wasn't sure how to pace it'. Others noted the need for more seating areas: 'needed more space to sit down', or more space is required: 'there are bottle necks at times with films'.

For a minority of participants, the spatial layout felt:

'confusing'

'quite hard to make our way around'

'some areas were a little tight as there were people standing viewing things which

made it hard for others to get by'

'there were times when I got lost'. 
A few respondents attached symbolic meaning to design and, for example, made analogies between the size of a space and the importance of the subject matter. The sample comment 'the size of the rooms/displays were proportionate to the importance of the information overall which was useful' is quite revealing of how visitors may attach meaning to content by means of its design. The comment 'I found the place a bit cramped which helped convey the cramp [conditions] of the Jews' points to how the walk through a cattle truck leading to the Auschwitz model is interpreted to symbolize the overcrowded conditions of the transportation of Jewish victims to the camps. Spatial layout shaped how visitors assign value and relevance to historical information, and ultimately create a coherent storyline of the Holocaust.

\section{Proximity to Original Artefacts}

In Holocaust exhibitions, original artefacts create "close encounters and the "right" atmosphere to help the visitor enter the "experience" of the Holocaust: arousing emotions and often forms of identification' (Holtschneider 2011: 98). Artefacts and replicas such as the dissecting table or the cattle truck act as 'crisis points' marking dramatic changes in the historical narrative. The audio guide encourages visitors to experience the physicality of the artefacts and, in doing so, places emphasis on the experiential dimension of their encounter with this history. For example, students are told to 'go over and feel it [the cattle truck]'. It is described as 'rough, heavy [...] designed for transporting freight and animals'. Original elements of the artefact are pointed out to visitors: 'If you look up you'll see the arched roof taken from this truck. And beneath your feet is the original flooring' (Imperial War Museum and Kharibian 2009: 37). It is not surprising that participants viewed artefacts as prompting powerful emotional reactions, and as facilitating a personal connection with this history. Items of emotional impact included clothing worn by victims e.g. 'The clothing on display made it easy to picture life back then', as well as personal artefacts found on the sites of mass murder, such as the broken glasses, keys, or silverware. For many participants it was the combined effect of material artefacts alongside photographs and video footage which proved to be particularly powerful. Someone stated this clearly: 'A combination of everything seen and heard, seeing the suffering of children was difficult. The dissection table was one of the first things to cause feelings of distress'.

Most participants assigned 'significance and importance' to items under glass cases and observed that 'well-lit cases drew more attention to them'. Personal items belonging to the victims 'attracted people from a distance'. Participants assigned greater meaning and importance to objects protected by glass covers. One visitor remarked that the frail condition of items in glass cases 'were clearly fragile and old which helped to show the length of time since the Holocaust'. The sense of proximity to objects owned by victims was not altered by their encasing in the glass case, but rather their value and relevance increased in the eyes of participants. Only a few respondents were of a different opinion: 'I found this to be an unsuccessful approach as it separated us from the history, making it difficult to understand'. The audio guide further encouraged students to engage with individual artefacts or sources as a way of understanding specific aspects of history. Object-led learning is central to the Imperial War Museum's educational programme and is incorporated into the educational sessions following students' visit of the exhibition. Artefacts are regarded as effective tools to 'explore the experiences of real people'. Donnelly further explains 'In working with this particular object we attempt to challenge students to consider how we know what we know about the past' (Donnelly 2018: para. 38).

While this is certainly a pedagogic method worth building on, within the exhibition space, visitors could be made more aware via text panels of how artefacts are contextualized and of why they appear in this space. Particularly difficult objects such as weapons, and objects of death such as the dissecting table, or of torture such as whips and bats present in this exhibition, should be carefully framed so that visitors are encouraged to think about ethical questions such as 'What do these object have to teach the contemporary visitor?' and 'Is it necessary to display such potentially emotionally harmful objects?' Since such objects are bound to provoke a visceral reaction, what are the moral responsibilities of the museum curators? Questions like these are certainly discussed by the curatorial team during 
the process of putting together the exhibition. Their educational value would increase if the visitors too could be made aware of discussions behind closed doors.

It is important also to state that the exhibition includes replica objects, such as the dissecting table; however, the distinctions between original and replica artefacts are not always obviously stated in the text panels. Curators capitalize on the power of authentic artefacts to engage visitors and to convey the relevance of this history in the present. To encourage ethical curatorship, the audience should be made aware of what is authentic, and what is a replica within this charged space.

\section{Interactive Displays}

In museum exhibitions, hands-on interactions mediated by technology are commonly used to facilitate engagement with the subject matter. Although 'hands-on' approaches have been used effectively, critics caution that it does not always equate with a 'minds-on approach' to learning or succeeds in instilling in visitors a sense of being active agents or active citizens in the world (Henning 2006: 312). In the Holocaust Exhibition, interactive displays are used mainly to enhance historical knowledge and to provide access to content. Participants in this study did find interactive displays to be an effective way to gain information and insight. Touch screens were deemed to be:

'good for information'

'the computers that were tapped that showed us loads of information'

'I liked the computers'

'I liked the interactive screen also; it gave a lot of information'

'understand more of a specific aspect'

'it made us think about what we were seeing and hearing'.

Most respondents agreed that interactive displays increased their engagement with the exhibition:
'it made it more interesting'
'made the experience feel a lot more real'
'improved the engagement and relatability of the experience'
'it allowed us to get involved and made us think about what we were seeing and hearing'
'it made the exhibition overall more engaging'.

Given the minimal use of hands-on displays, most participants remarked on the presence of seating areas which they viewed as not just providing a chance to have a rest, but also as enabling a deeper reflection and emotional involvement:

'the exhibition was very long, so the benches/chairs were very welcome'

'nice to have benches/chairs to rest on throughout'

'I can tell that if someone was very emotional benches can come in handy'.

Others noted the seating areas facilitated a better focus on video testimonies:

'I liked when there were benches or chairs near video screens so you could sit down and watch it properly'.

Three themes stand out from visitors' responses to the above-mentioned elements of design: 1) the impact of design on visitors' sense of engagement (both cognitive and affective); 2) the sense of focus and direction mediated by design choices; and 3) a symbolic reading of history facilitated by design. Participants' comments further reveal how historical meaning is shaped by design choices. Design not only invites empathy and identification with the persecuted groups (as noted in studies by Vivian Patraka (1999), Alison Landsberg (2004), Carolyn Dean (2004), Jens Andermann and Silke Arnold-de Simine (2012), and Jennifer Hansen-Glucklich (2014)). Design also works to transmit historical knowledge, directing attention to specific chapters of the historical narrative, whilst downplaying others. Design elements act to draw attention to, to highlight, or to downplay historical sequences, leading visitors to a selective engagement with the subject matter. By means of design, events in a historical narrative 
gain in importance and are perceived as significant, or as defining of that history. Other events may be perceived as marginal and less significant. Design not only stages historical narratives, but drives the narrative forward, it holds visitors' attention, and in crucial ways, it shapes historical knowledge and understanding.

The performativity of exhibition design is reflected in participants' answers to the survey question: 'Did the exhibition design enhance your ability to remain focused on the historical information being presented?' Most participants thought design enhanced their focus (x25), a few were critical $(x 9)$, and a minority gave mixed responses $(x 2)$. Several themes emerge from participants' comments:

1) A sense of flow/immersion and of movement facilitated by design was remarked upon. Seah and Cairns (2008: 2) describe flow as 'a harmonious psychological state whereby a person is engaged in an activity that is challenging, but not beyond the skills of the person and has a clear sense of progression towards a goal'. During 'flow', people are wholly engaged in an activity, excluding all other concerns. Participants remarked that the exhibition was:

'well-structured/it flowed continuously'

'it was all very engrossing'

'you are usually moving, meaning you don't get bored'

'kept you moving throughout it onto new topics, so you didn't get bored'

'I felt like I could easily move around and remain focused while exploring'.

The sense of flow was produced by the clear organization of the exhibition into sections and chapters and by a lack of monotony:

'I liked that different points were split into different sections'

'it was split into different sections to avoid appearing monotonous'.

For a few respondents, the sense of flow was disrupted by a clash between two channels of communication conveying similar information, as for example the audio guide and the textual panels:

'when listening to the phones (audio guide) it was hard to read the information too'

'it was hard to read and listen at the same time' (also in reference to the audio testimonies by survivors).

2) A sense of connection is linked to how the chapters of the historical narrative were forged together to create a story:

'the exhibit unfolded the story step by step'

'it was all linked and close together'

'it was all connected'.

3) A sense of focus and engagement with the exhibition's content is sustained by the exhibition's interplay of diverse media: textual, aural, linguistic, spatial, and visual media. The diversity and variety of media used, as well as the large number of material artefacts, were appreciated by visitors:

'it provided many different forms and ways of acquiring information'

'everywhere you looked there was more information and items'

'there was a lot to look at, at all categories and big moments highlighted'

'it wasn't a plain, boring wall, the different rooms and levels made it easier to focus'

'it used a variety of aids - pics, text, audio which kept one interested'

'the diversity and variety of shape, size, lighting and content of each room made the exhibition very easy to engage in'.

Overall, these responses reflect a perception of the Holocaust Exhibition as rich, coherent and well organized, and of design and content as coming together quite seamlessly to construct a focused and clear narrative. None of the participants in the study remarked on an overabundance of reading materials. As Roppola observed in her study (2012: 196), 'fatigue, boredom and limited timeframes were conditions recurrently affirmed by visitors' in relation to excessive reading materials. The above comments suggest that the Holocaust Exhibition 
is perceived to be high in coherence and high in engagement, denoting that the visitor's focus was appropriately channelled by means of media, spatial layout and lighting.

\section{Other Visitors' Behaviours}

In addition to design choices, this study showed that other visitors' behaviours played a role in how participants experienced the exhibition. Most participants reported that they were not affected by the behaviour of other visitors because this was 'respectful' and 'quiet' - attitudes they deemed appropriate for the exhibition's content. Some observed how other people's 'respectful', 'quiet', 'sad', or 'emotional' attitudes influenced their own reactions. It encouraged them to act in a similarly silent and respectful way, and it increased some participants' ability to focus and to think about what they were viewing. Participants were influenced by:

'seeing other people's disbelief'

'everybody looked sad, so there was an atmosphere'

'the fact that everyone was quiet emphasized the seriousness'

'everyone was very quiet and respectful which made the exhibit feel appropriately sombre'

'everyone was quiet and respectful which was beneficial'

'everyone being quiet encouraged me to be quiet'

'as it was quiet which helped one to appreciate the exhibition and fully comprehend it' 'everyone was quiet and respectful and moved calmly and slowly'

'I liked how it was quiet other than the videos, because it allowed you to think more'.

A few remarked upon less appropriate behaviours such as 'taking photos' in an exhibition where this activity is not allowed, or phones ringing, and inconsiderate actions such as when visitors obstructed access to panels by 'walking in front of me', or 'laughing with friends'. These behaviours were deemed to be distracting, interfering with one's ability to concentrate on the information given in the exhibition. There is a clear understanding of what constitutes acceptable behaviours among the participants in this study. That students approach this space in silence, which reflects a 'ritualised form of remembrance', is known to the museum's educators (Donnelly 2018: para. 14). However, the above responses also reveal that this attitude is no longer dominant. Donnelly is well aware of this, as she states, 'in recent years we have seen this mode of behaviour begin to change. More visitors can be overheard discussing with one another the objects, photographs, or film around them' (Donnelly 2018: para. 14).

\section{Discussion}

This research study of young visitors' experience of the Holocaust Exhibition shows that the design choices, as well as other visitors' behaviours, indeed influence visitors' emotional and cognitive responses in many significant ways. Lighting fulfils multiple functions: 1 ) it encourages a commemorative stance, which is not intended by exhibition developers; 2) it enables visitors' access to content; and 3) it channels visitors' attention to specific moments and events in the history of the Holocaust. Furthermore, the contrastive use of dark and of well-lit space conveys two fundamental perceptions of Holocaust memorial museums and exhibitions, as spaces for both education and commemoration. Often these dimensions succeed in working together to create the moral message and fulfil the mission of memorial museums. The message conveyed by such museums is that learning about the Holocaust has ethical implications, placing an obligation to both remember what happened and also to ensure similar events do not happen again.

This research study also shows that, in museum spaces such as the Holocaust Exhibition (which is not deemed to be a space of commemoration), design choices may sometimes fail to impact visitors in the intended way, therefore undermining the purposes of exhibition curators. The comments made by participants in this study suggest that remembering the victims and learning about their plight are regarded as being integral to their experience of the Holocaust Exhibition. Having said that, some participants note that an overly commemorative mood (in comments such as 'too dark') may interfere with their access to information. Such comments should alert museum professionals to the impact of design on the exhibition's educational goals. 
This risk may however be avoided. The newly planned Holocaust and World War II Galleries due to open to the public in 2021 will not employ dark space. This design choice has been revealed during informative meetings with the public organized by the Holocaust Exhibition team James Bulgin (Exhibition Content Leader) and Rachel Donnelly (Learning Programme Manager). Rather, the new exhibition will use light to show that the events of the Holocaust happened in broad daylight, and that it happened whilst others looked on. This realist approach to design is symbolic in its own ways. It brings the Holocaust to light as a real event as opposed to an event enshrined in mystery. It further announces a departure from established Holocaust exhibition design conventions, which focus on the tension between the use of dark and well-lit space. At a symbolic level, well-lit space has been associated with education and cognition (Messham-Muir 2015). It encourages direct visualization of historical evidence. Darkness, on the other hand, is less about elucidation and more about emotion and the suspension of conclusive understanding. Design can promote an experience of unsettlement which appeals to both cognition and emotion. It facilitates learning and is crucial in articulating the factuality of the Holocaust. On the other hand, design mediates emotion and creates charged spaces that resist allowing facts to settle into redemptive, or passive knowledge. Shoshana Felman, a literary critic and professor of comparative literature, explains that learning about the Holocaust lies 'not merely in new information, but primarily, in the capacity of their recipients to transform themselves in view of the newness of that information [author's emphasis]' (Felman and Laub 1992: 53). She recalls a moment when teaching about the Holocaust transformed information into 'active knowledge' which was capable of producing 'a crisis of witnessing' in her students. Design can mediate a 'crisis of witnessing'. It can call upon visitors 'to be performative, not just cognitive insofar as they strive to produce and to enable, change'. While fundamental transformations as a result of learning about the Holocaust may be difficult to validate by empirical research, knowing better how visitors to Holocaust exhibitions make sense of design is possible.

This research study shows that elements of exhibition design which engage both emotion and cognition play a crucial role in shaping the visitor experience. Holocaust educator and scholar Simon I. Roger explains that active witnessing of the past engages both cognition and emotion. He states that 'to witness in a manner that opens the possibility of altering an aspect of one's reality requires a dialectical coupling of affect and thought, implicating the self in the practice of coming to terms with the substance and significance of history' (Roger 2014: 200). The practice of public history that museums engage in is not simply about providing information about the past. It is also about proposing a meaningful framework of experience, learning and reflection, within which the past attains meaning in the present. As we understand visitor reactions more fully, and in all their diversity, we begin to realize that what is required is exhibition practices which foster a 'dialectical coupling of affect and thought'. The communicative and performative design strategies can be applied to future Holocaust exhibitions in several ways which I would like to suggest. These are:

1) to make clear that historical narratives contain inconsistencies and contradictions, which are not easily resolved by the information currently available. Also, that more than 70 years on, Holocaust research continues to evolve and to inform such narratives;

2) to provide images and texts which are visually compelling whose effect on the viewer is not limited to shock value but goes further, provoking deeper consideration of the content and how to respond to it;

3) to create a multilayered narrative which can be accessed in multiple ways, thus giving visitors pathways by which they can further pursue issues that they are curious or uncertain about; and

4) to provide access to a variety of visitor responses to the exhibition, as well as an opportunity to add one's own views to a dialogue inspired by the exhibit.

As the Imperial War Museum's Holocaust Exhibition is redesigned, the aspirations of designers to inform audiences ought to be supplemented by consideration of the impact of design on 
the cognition and emotion of the visitor, as well as its potential to mobilize them to act morally. This research study, albeit at small scale, has shown that exhibition design is by no means a neutral actor, but acts as an active agent, with a force which influences the visitor on both an emotional and intellectual level.

In the future, audience research studies on a larger scale are necessary to gauge how visitors of different backgrounds and age groups, including those with a higher level of subject matter knowledge, respond to historical content staged by exhibition designers. It is common for museums, such as the Imperial War Museum, to develop robust programmes of visitor consultations, which provide feedback on specific elements of design and curation. However, more could be achieved in terms of the scope and the scale of such programmes. New methods of collecting feedback could be implemented by using, for example, immersive technologies such as Virtual Reality, Augmented Reality or Mixed Reality. These could assist museum professionals to reach a more nuanced understanding of audience responses. They could provide a flexible platform to test, interrogate and refine new exhibition concepts before they have been implemented as fully fledged projects. Virtual platforms might include tours of exhibition projects still in the design phase. These can integrate different methods of capturing audience responses, such as eye-tracking and emotion recognition, and can prompt visitors to react to specific elements of exhibition design and to reflect on specific questions raised by design. Such platforms are not only beneficial for developers, but also provide opportunities to learn about the past, reflect on and make sense of visitors' experience, and crucially exercise their own critical thinking skills. Visitor reactions, as shown in this research study, can provide valuable insight into how design choices influence the effectiveness of the transmission of historical knowledge, and offer new ideas as to how content can be presented in ways that are more meaningful and engaging.

Received: 20 October 2019 Finally accepted: 12 May 2020

\section{Acknowledgments}

I gratefully acknowledge the assistance and support received from the Holocaust Team, and in particular the generous support from Rachel Donnelly (Learning Programme Manager) at the Imperial War Museum in London, who has generously facilitated the planning and organization of the research study, and the collection of survey data from the two participating school groups during March to June 2017. I would like to thank all the young participants and their teachers who agreed to take part in this research by offering their time and by sharing their feelings and thoughts about the Holocaust Exhibition. This work has been financed by the Swedish Research Council (Vetenskapsrådet) under the Grant [421-2014-1289].

\section{Notes}

1 Imperial War Museum, 'About', 2019. https://www.iwmshop.org.uk/pg/108/About-Us, accessed 7 June 2020.

2 The Holocaust Educational Trust, 'Lessons from Auschwitz Programme', 2019. https:// www.het.org.uk/lessons-from-auschwitz-programme, accessed 8 June 2020.

\section{References}

Andermann, J. and Arnold-de Simine, S. (2012) 'Introduction: Memory, Community and the New Museum', Theory, Culture \& Society, 29 (1) 3-13.

Bagnall, G. (2003) 'Performance and Performativity at Heritage Sites', Museum and Society, 1 (2) 87-103. 
Bardgett, S. (1998) 'The Genesis and Development of the Imperial War Museum's Holocaust Exhibition Project', The Journal of Holocaust Education, 7 (3) 28-37.

(2004) 'The Depiction of the Holocaust at the Imperial War Museum since 1961', Journal of Israeli History, 23 (1) 146-56.

Bardgett, S. and Imperial War Museum (2010) The Holocaust Exhibition: Ten Years On, London: Imperial War Museum.

Bernard-Donals, M. (2018) 'Figures of Memory at the United States Holocaust Memorial Museum', in Andy Pearce (ed) Remembering the Holocaust in Educational Settings, London: Routledge (Taylor and Francis. Kindle Edition).

Casey, V. (2005) 'Staging Meaning: Performance in the Modern Museum', TDR The Drama Review, 49 (3) 78-95.

Cole, T. (2006) 'Nativization and Nationalization: A Comparative Landscape Study of Holocaust Museums in Israel, the US and the UK', Journal of Israeli History, 23 (1) 130-45.

Dean, C.J. (2004) The Fragility of Empathy after the Holocaust, Ithaca: Cornell University Press.

Donnelly, R. (2018) 'Imperial War Museums: Reflecting and Shaping Holocaust Memory', in Andy Pearce (ed) Remembering the Holocaust in Educational Settings, London: Routledge (Taylor and Francis. Kindle Edition).

Falk, J. and Dierking, L. (1992) The Museum Experience, Washington, DC: Whalesback Books.

(2000) Learning from Museums: Visitor Experiences and the Making of Meaning, Walnut Creek, CA: AltaMira.

Felman, S. and Laub, D. (1992) Testimony: Crises of Witnessing in Literature, Psychoanalysis and History, London: Routledge.

Foster, S., Pettigrew, A., Pearce, A., Hale, R., Burgess, A., Salmons, P. and Lenga, R.A. (2016) What Do Students Know and Understand about the Holocaust? Evidence from English Secondary Schools, London: Centre for Holocaust Education, UCL.

Greenberg, R. (2007) 'Mirroring Evil, Evil Mirrored: Timing, Trauma and Temporary Exhibitions', in Griselda Pollock and Joyce Zemans (eds) Museums After Modernism: Strategies of Engagement, 104-18, Oxford: Blackwell.

Hansen-Glucklich, J. (2014) Holocaust Memory Reframed: Museums and the Challenges of Representation, New Brunswick: Rutgers University Press.

Henning, M. (2006) 'New Media', in Sharon Macdonald (ed) A Companion to Museum Studies, 302-18, Malden, MA: Blackwell.

Holtschneider, H. (2007) 'Victims, Perpetrators, Bystanders? Witnessing, Remembering and the Ethics of Representation in Museums of the Holocaust', Holocaust Studies, 13 (1) 82-102.

(2011) The Holocaust and Representations of Jews: History and Identity in the Museum, London: Routledge Jewish Studies Series. 
Hooper-Greenhill, E. (2006) 'Studying Visitors', in Sharon Macdonald (ed) A Companion to Museum Studies, 362-76, Malden, MA: Blackwell.

Imperial War Museum and Kharibian, L. (2009) 'Imperial War Museum, Holocaust Galleries, 'A Level Students' guide' [internal museum document].

Jinks, R. (2013) 'Holocaust Memory and Contemporary Atrocities. The Imperial War Museum's Holocaust Exhibition and Crimes against Humanity Exhibition', in Caroline Sharples and Olaf Jensen (eds) Britain and the Holocaust: Remembering and Representing War and Genocide, 142-60, Basingstoke: Palgrave Macmillan.

Klein, L. (1991) 'Team Players', Museum News, March-April, 70 (2) 44-5.

Kushner, T. (2001) 'Oral History at the Extremes of Human Experience: Holocaust Testimony in a Museum Setting', Oral History 29 (2) 83-94.

(2002) 'The Holocaust and the Museum World in Britain: A study of Ethnography', Immigrants \& Minorities, 21 (1-2) 13-40.

Landsberg, A. (2004) Prosthetic Memory. The Transformation of American Remembrance in the Age of Mass Culture, New York: Columbia University Press.

Lawson, T. (2003) 'Ideology in a Museum of Memory: A Review of the Holocaust Exhibition at the Imperial War Museum', Totalitarian Movements and Political Religions, 4 (2) 173-83.

Macken-Horarik, M. (2004) 'Interacting with the Multimodal Text: Reflections on Image and Verbiage in ArtExpress', Visual Communication, 3 (1) 5-26.

Messham-Muir, K. (2004) 'Dark Visitations: The Possibilities and Problems of Experience and Memory in Holocaust Museums', Australian \& New Zealand Journal of Art: Art and Ethics, 5 (1) 97-111.

(2015) 'Into Darkness: Affect and Dark Space in Holocaust Exhibitions', Journal of Curatorial Studies, 4 (1) 434-57.

McCarthy, J. and Ciolfi, L. (2008) 'Place as Dialogue: Understanding and Supporting the Museum Experience', International Journal of Heritage Studies, 14 (3) 247-67.

Neuman, E. (2014) Shoah Presence: Architectural Representations of the Holocaust, Farnham: Ashgate.

Patraka, Vivian M. (1999) Spectacular Suffering: Theatre, Fascism, and the Holocaust, Bloomington: Indiana University Press.

Pearce, A. (2014) Holocaust Consciousness in Contemporary Britain, London \& New York: Routledge.

Rabinowitz, R. (1991) 'Exhibit as Canvas', Museum News, March-April, 70 (2) 34-8.

Roger, S.I. (2014) A Pedagogy of Witnessing. Curatorial Practice and the Pursuit of Social Justice, New York: State University of New York Press.

Roppola, T. (2012) Designing for the Museum Visitor Experience, New York: Routledge.

Seah M. and Cairns, P. (2008) 'From Immersion to Addiction in Videogames', in Proceedings of the 22nd British $\mathrm{HCl}$ Group Annual Conference on $\mathrm{HCl} 2008$ : People and Computers XXII: Culture, Creativity, Interaction, vol. 1, 55-63, Liverpool: University of Liverpool Press. 
Shosh Rotem, S. (2013) Constructing Memory: Architectural Narratives of Holocaust Museums, New York: Peter Lang.

Stenglin, M.K. (2004) Packaging Curiosities: Towards a Grammar of Three- Dimensional Space, Ph.D. Thesis. Sydney: University of Sydney.

Stiles, E. (2016) Narrative, Object, Witness: The Story of the Holocaust as Told by the Imperial War Museum, London, Ph.D. Thesis. Winchester: University of Winchester.

Wiesel, E. (1978) 'Trivializing the Holocaust: Semi-Fact and Semi-Fiction', New York Times, 16 April, 29.

Wollaston, I. (2005) 'Negotiating the Marketplace: The Role(s) of Holocaust Museums Today', Journal of Modern Jewish Studies, 4 (1) 63-80.

Yellis, K. (2010) 'Cueing the Visitor: The Museum Theater and the Visitor Performance', Curator, 53 (1) 87-102.

\section{Author}

Diana I. Popescu

Associate Research Fellow,

Pears Institute for the study of Antisemitism

Birkbeck College

United Kingdom

d.popescu@bbk.ac.uk 